Article

\title{
The Effect of Airport Self-Service Characteristics on Passengers' Perceived Value, Satisfaction, and Behavioral Intention: Based on the SOR Model
}

\author{
Jong-Hyeon Kim and Jin-Woo Park *(D) \\ School of Business, Korea Aerospace University, Goyang-si 10540, Korea; jonathan@airport.kr \\ * Correspondence: jwpark@kau.ac.kr; Tel.: +82-2-300-0354
}

Received: 21 August 2019; Accepted: 23 September 2019; Published: 27 September 2019

\begin{abstract}
This paper analyzes the effects of airport self-service characteristics on behavioral intention through the perceived values and satisfaction in passengers based on the Stimulus-Organism-Response (SOR) model. For this purpose, a survey was conducted with passengers having used self-service technologies (SSTs) at Incheon International Airport. A total of 400 questionnaires were then analyzed using structural equation modeling. Four SST factors-functionality, enjoyment, customization, and convenience-were found to have significant effects on behavioral intention through the perceived values and customer satisfaction. As for the moderating effects of self-efficacy and waiting time, significant differences were found in the effects of the airport self-service characteristics. The results of this study are expected to be useful as basic data to aid strategies to develop and improve SSTs at Incheon International Airport.
\end{abstract}

Keywords: self-service technologies (SSTs); perceived value; self-efficacy; satisfaction; behavioral intention

\section{Introduction}

It can be said that a smart airport is more conveniently, safely, and efficiently operated, thanks to the application of up-to-date information and communication technologies such as artificial intelligence, robot technology, the Internet of Things, and big data. Some advanced airports that have recently been opened outside of Korea are endeavoring to reduce immigration waiting times and ease passenger discomfort via self-service strategies. This includes the principle steps for immigration, as well as passenger check-ins, luggage checks, automatic immigration control, self-boarding, booking changes, and checked luggage management. In this way, smart airports are leveraging self-service technologies (SSTs). Within airports, checks-ins take significant amounts of time during peak periods. SSTs are accordingly being promoted because they increase airport efficiency, reduce waiting times, offer passengers greater convenience, and save costs and space.

Studies have indicated that in principal areas such as ticketing, check-in, and luggage management, SSTs can improve processing capacity [1], save costs, improve consumer service, and enable airports to lead the way in terms of the services they offer [2]. Incheon Airport's air transport performance (as of 2018) was 68,259,763 passengers (7th in the world), 387,497 flights and 2,952,069 tons of international cargo (3rd in the world), and has been growing at an annual average of $7.3 \%$ (flights) since its opening [3]. Regarding the principal SSTs at Incheon International Airport, self-check-ins accounted for $37 \%$ (among passengers in participating airlines), self-bag drops accounted for $9.8 \%$ (among passengers in participating airlines), and automated immigration control accounted for 38.9\% (among passengers routed through immigration) (Incheon International Airport Smart Check-in Management Report, 2018). Although the application of SSTs in the airport industry is becoming more important by the day 
and research on SSTs effects in diverse industries have been conducted, most studies have focused on the effects of airport SSTs on passenger behavioral intention [4-7]. Because self-service characteristics can depend on passenger self-efficacy and wait times, research on how these two factors have an effect on self-service has become more important $[8,9]$. However, the moderating effect of these variables have been ignored in the previous studies. Therefore, the present study aims to analyze the effects of airport self-service characteristics on the perceived value, customer satisfaction, and behavioral intention through the moderating variables (self-efficacy and waiting time). It also attempts to facilitate the successful introduction of SSTs to airports and presents a strategic method of differentiating service provision on the basis of the Stimulus-Organism-Response (SOR) integration model, which is frequently applied to determine consumer behavior in the area of behavioral science. The results of this study are expected to lay the groundwork for further research on the realization of a smart airport combined with up-to-date Technology-Based Self-Service (TBSS) and contribute to the establishment of an advanced strategy to introduce TBSS to airports successfully and provide differentiated operation service.

\section{Theoretical Background}

The S (stimulus)-O (organism)-R (response) model suggested by Mehrabian and Russell [10] assumes that various environmental stimuli surrounding individuals have an impact on their psychological state and, ultimately, on their consumption behavior. Stimuli refer to those from the external environment surrounding individuals and the model assumes that various external stimuli related to decision-making affect their inner state [11,12]. Organism refers to an individual's inner state and includes feelings, emotions, and cognitive behavior [13]. Response is a behavioral reaction that results from the stimuli in the external environment and the inner procedures of the organism and includes psychological attitudes or behavioral reactions [14]. The SOR model has been widely used for the systematic analysis of human behavioral intentions by focusing on internal factors of humans $[15,16]$. Based on the literature review, this study applies the SOR integration model to investigate the influence of airport self-service technology on customer behavioral intention.

Dabholkar [17] defined technology-based self-service (TBSS) as an activity or benefit that allowed service providers to base service on technologies so that customers could serve themselves. Meuter et al. [18] defined TBSS as any means of technological connection that allowed customers to produce or use service personally, rather than interacting with an employee for a service provider. SSTs at airports significantly benefit airport managers, airlines, and passengers. The application of SSTs can bring about positive effects by providing standardized services, by increasing service provision options, by improving productivity and efficiency, by reducing costs, and by improving satisfaction [19]. Consumers may use a compensatory process to evaluate TBSS characteristics [20]. The qualitative research designed by Dabholkar [16] detected six TBSS properties-time, effort, complexity, reliability, accuracy, and enjoyment. Zhu et al. [21] divided TBSS properties at banks into seven categories-ease of use, convenience, time saving, privacy, multi-functionality, accuracy, and use of up-to-date IT. Ahn et al. [22] divided them into four categories-functionality, enjoyment, design, and customization - and Lin et al. [23] presented seven TBSS quality characteristics-functionality, enjoyment, security, assurance, design, convenience, and customization.

Further, the customer perceived value of the airport's self-service technology characteristics was defined as "the comprehensive satisfaction assessment of the users' with the services provided" by referring to the study on the effect of perceived value on satisfaction [24]. Technology-based self-service (TBSS) is used in combination with SST, but it is the same term [17]. Self-service technology (SSTs) is defined as "technological interfaces that enable customers to produce a service independent of direct service employee involvement" [18]. Perceived value is "The consumer's overall assessment of the utility of a product based on perceptions of what is received and what is given" [25]. The effects of TBSS characteristics on perceived value have been researched by several researchers. For example, Wang et al. [26] found that enjoyment had a positive effect on the user's value perception. Lee et al. [27] also noted that there was an important relationship between enjoyment and perceived value. Similarly, 
some researchers have verified relationships between TBSS characteristics and perceived value. Marimon et al. [28] found that functionality of technology service had a positive affect on perceived value and Sigala [29] showed that customization had a positive effect on service user's value perception.

Based on the literature review, the present study presents five characteristics-functionality, enjoyment, security, convenience, and customization-to take the TBSS characteristics and operational environment into account. It then formulates the following hypotheses to determine the effects of the TBSS characteristics on the perceived values.

Hypothesis 1 (H1). Functionality will significantly affect the perceived values.

Hypothesis 2 (H2). Enjoyment will significantly affect the perceived values.

Hypothesis 3 (H3). Security will significantly affect the perceived values.

Hypothesis 4 (H4). Customization will significantly affect the perceived values.

Hypothesis 5 (H5). Convenience will significantly affect the perceived values.

Zeithaml [25] defined perceived values as those involving the transaction between a customer's benefit from using a service and the evaluation of investment in it. Sweeney and Soutar [30] defined perceived values as a multidimensional concept that might serve as a consumer's criterion and the goal of making a decision to choose a certain brand and purchase a product. The themes covered by previous studies on perceived values include the causal relations between perceived values and customer satisfaction and loyalty [31,32], the association between perceived values and the switching intention [33,34], and the association between perceived values and reliability [24].

Research on customer satisfaction has mainly been based on Oliver's [35] expectancy disconfirmation theory to measure and determine customer satisfaction through such variables as expectation, product practicality, and expectancy disconfirmation. Hellier et al. [36] defined customer satisfaction as a customer's expectation of service and need for expectation confirmation, as well as the general joy and pleasure perceived during service performance. Kotler and Keller [37] defined it as a customer's disappointment and joy from products in comparison with their known results. Gopinath and Nyer [38] indicated that satisfaction was composed of two factors-cognition and emotion-and Odekerken-Schroder et al. [39] reported that satisfaction might include the cognitive and emotional evaluation of certain goods or services. It can be said, therefore, that satisfaction is composed of cognitive and emotional factors.

Behavioral intention can be defined as the intention to use and this implies a motivator affecting an individual's subjective state and behavior [40]. In general, as behavioral intention increases, the likelihood that the behavior is performed also increases [41]. Zeithaml [42] notes that behavioral intention is a concept that covers word-of-mouth or repurchase intention related to goods or services and it can be divided into revisit and word-of-mouth intention according to experiences or awareness. Word-of-mouth plays a positive role related to goods or services to be purchased because it tends to induce potential customers to make more revisits because the effects are being recommended and positive experiences are being spread [43]. Cronin et al. [44] presented the component of behavioral intention, re-use intention, recommendation intention, and friendly attitude, and used them to measure behavioral intention. Dawn and Thomas [45] used economic and social behavior to measure behavioral intention. In addition, behavioral intention is a comprehensive concept and can be measured by classifying it into several components, and many studies have used re-use intention and word of mouth to construct behavioral intention [46].

Based on the literature review, this study formulates the following hypotheses to analyze the effect of perceived value of TBSS characteristic factors on airport's reuse intention through satisfaction. 
Hypothesis 6 (H6). Perceived values will significantly affect TBSS satisfaction.

Hypothesis 7 (H7). Perceived values will significantly affect general satisfaction with an airport.

Hypothesis 8 (H8). Perceived values will significantly affect behavioral intention.

Hypothesis 9 (H9). Satisfaction with SSTs at an airport will significantly affect general satisfaction with the airport.

Hypothesis 10 (H10). Satisfaction with SSTs at an airport will significantly affect behavioral intention.

Bandura [8] defined self-efficacy as a personal belief that one could successfully elicit the behaviors required to achieve certain results. Schunk [47] defined self-efficacy as an individual's own determination of whether they could fulfill a given duty. Gist and Mitchell [48] defined it as an individual's belief that he or she could perform desired tasks and behavior well. Bandura [49] noted that as the level of self-efficacy increased, individuals were more likely to be committed and devoted to a given task and were more willing to set and achieve a challenging goal. Based on the previous studies, it is clear that the moderating role of self-efficacy in terms of its effects on the perceived values of airport TBSS is important. The same is true regarding the effects on satisfaction with airport TBSS, and on the intention to reuse airport TBSS. Accordingly, it is predicted that when self-efficacy increases and the level of fear decreases, behavioral intention will increase.

To measure the self-efficacy of the use of airport self-service technologies, the self-efficacy was defined as "individual belief that the use of airport self-service technologies can be implemented successfully" based on preceding studies such as Bandura [49], Bandura [50], Sherer et al. [51], Delroy and Mark [52], Schunk [47], Gist and Mitchell [48], Huebner [53], Gardner and Pierce [54], Dabholkar and Bagizzi [55], Shamdasani et al. [56]. The moderating role of self-efficacy was studied by various researchers. For instance, Lee et al. [27], Hill et al. [57], Deforche et al. [58], and Sung et al. [59] showed the influence and the importance of the moderating role of self-efficacy. Therefore, in this study, the following hypotheses are formulated to analyze the effect of the moderating effect on the self-efficacy of the individual's on the TBSS characteristics and perceived value.

Hypothesis 11 (H11). The effects of the TBSS characteristics on the perceived values will differ significantly according to an individual's self-efficacy.

Waiting refers to the phenomenon in which a customer waits for a service. This phenomenon starts from the moment the customer gets ready to be served and continues until the moment the service is initiated. It exists as part of the interrelationship between the customer and service provider [60]. Studies on perceived waiting from the perspective of customer satisfaction have demonstrated that the actual waiting times affect customer satisfaction, with perceived waiting time having more decisive effects than actual waiting time [61]. Moreover, the incongruity between perceived and actual waiting time affects customer satisfaction [62]. Based on the literature review [63-67] on waiting time, it was defined as an evaluation of the individual's subjective evaluation on the waiting time of the process of using the self-service technology and the difference from the post-experimental result of the customer's prior expectation. The moderating role of waiting time has been researched by several previous studies. For example, Djelassia et al. [9] and Pruyn et al. [68] showed the influence and the importance of the moderating role of waiting time. Therefore, the following hypotheses are formulated based on literature review to evaluate the satisfaction of perceived waiting time after using airport self-service technology.

Hypothesis 12 (H12). The effects of the TBSS characteristics on the perceived values will differ significantly according to the individual's waiting time. 
This study performs an empirical analysis to determine the structural effects of the TBSS characteristics at Incheon International Airport on passengers' behavioral intentions through the perceived values and customer satisfaction. The research model was developed, as shown in Figure 1, based on the literature review.

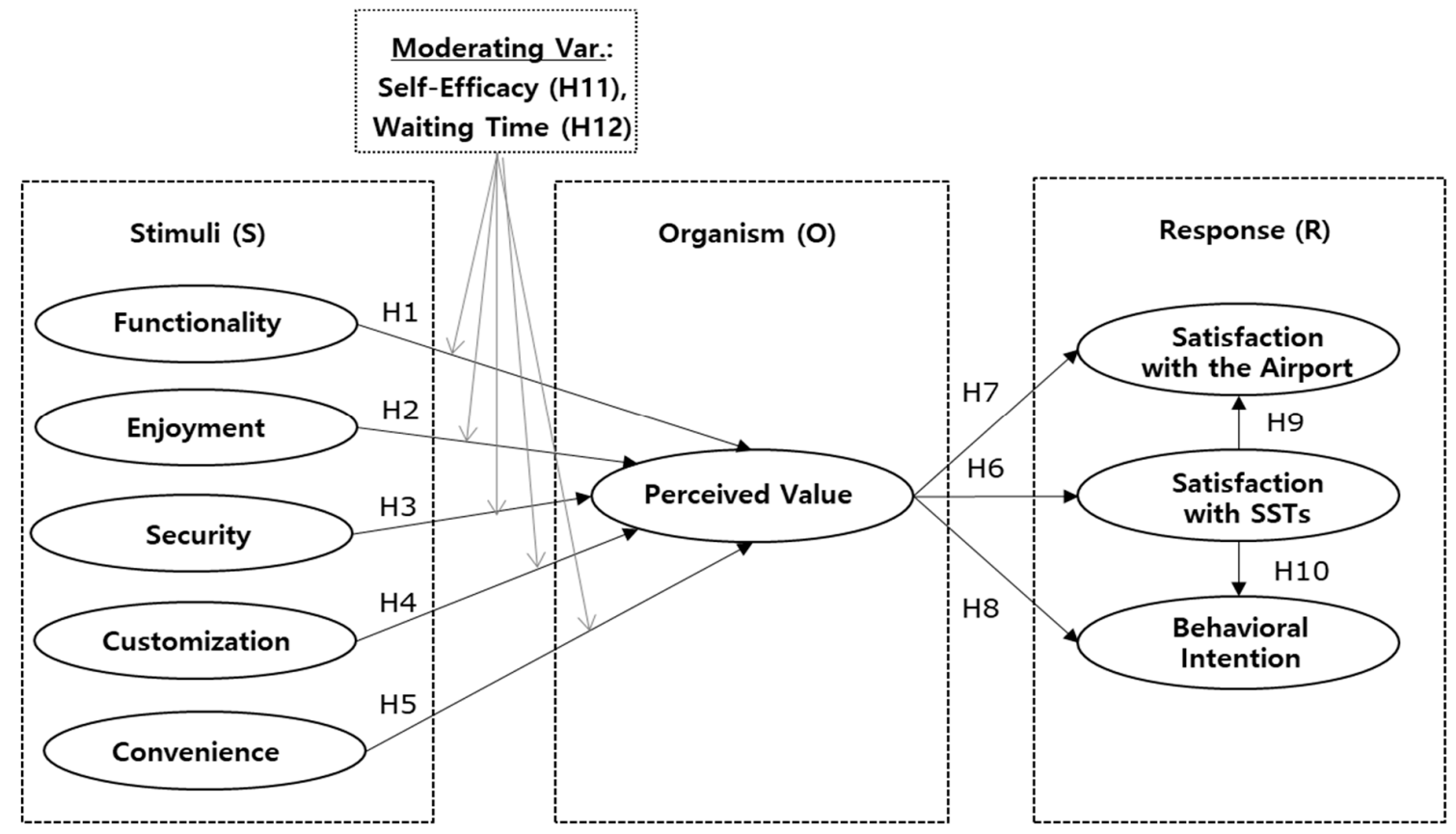

Figure 1. Research model.

\section{Methodology}

The questionnaire was developed by revising and complementing items in the preliminary survey based on the literature review. It contained six areas-airport SST characteristics, perceived values, behavioral intention, demographic characteristics, SST utilization behavioral, and passenger characteristics and utilized the 7-point Likert scale, with scores ranging from 1 (strongly disagree) to 7 (strongly agree). Table 1 below shows each item for functionality, enjoyment, security, customization, convenience, perceived value, satisfaction with SSTs, satisfaction with the airport, and behavioral intention.

To assess customer satisfaction with the TBSS characteristics, cognitive satisfaction is measured using Oliver's [69] customer satisfaction scale, and the emotional satisfaction that the TBSS characteristics might elicit from customers is measured using an adaptation of Martin's [70] scale.

The survey respondents were South Koreans who had utilized SSTs at airports from 2-28 October 2018. Given that the respondents were SST users, a researcher made a personal visit to the boarding lounge in the airside passenger terminals at Incheon International Airport to convey a better understanding of the questionnaire and raise the response rate. Of the 450 questionnaires distributed, 438 copies were returned. A total of 400 were analyzed after 38 copies that were incomplete or contained remarkably insincere answers were excluded. 
Table 1. Measurement items.

\begin{tabular}{|c|c|c|c|}
\hline Concept & Variable & Item & Related Studies \\
\hline \multirow{5}{*}{$\begin{array}{l}\text { Stimuli } \\
\text { (S) }\end{array}$} & Functionality & $\begin{array}{l}\text { Self-service technology at the airport allows you to complete } \\
\text { procedures quickly. } \\
\text { Airport self-service technology has clear service procedures. } \\
\text { I think it is efficient to use airport self-service technology. } \\
\text { Airport self-service technology is free of errors in each service } \\
\text { item and function. }\end{array}$ & $\begin{array}{l}\text { Meuter et al. (2000) [18], } \\
\text { Dabholkar \& Bagozzi (2002) [55], } \\
\text { Wang et al. (2006) [71], } \\
\text { Collier \& Sherrell (2010) [72] }\end{array}$ \\
\hline & Enjoyment & $\begin{array}{l}\text { Using airport self-service technology is interesting. } \\
\text { I'm curious about self-service technology at the airport. } \\
\text { It is interesting to use airport self-service technology. } \\
\text { The process of using the airport's self-service technology is } \\
\text { enjoyable. }\end{array}$ & $\begin{array}{l}\text { Dabholkar (1996) [17], } \\
\text { Eighmey \& McCord (1998) [73], } \\
\text { Dabholkar \& Bagozzi (2002) [55], } \\
\text { Venkatesh (2006) [74], } \\
\text { Collier (2013) [75] }\end{array}$ \\
\hline & Security & $\begin{array}{l}\text { My personal information is unlikely to be leaked while using } \\
\text { airport self-service technology. } \\
\text { I think that my personal information is safely protected while } \\
\text { using airport self-service technology. } \\
\text { Airport self-service technology does not share personal } \\
\text { information with other systems. } \\
\text { Self-service technology at the airport will keep my } \\
\text { immigration records confidential. }\end{array}$ & $\begin{array}{l}\text { Parasuraman (2000) [76], } \\
\text { Meuter et al. (2000) [18], } \\
\text { Lin \& Hsieh (2011) [23] }\end{array}$ \\
\hline & Customization & $\begin{array}{l}\text { Airport self-service technology provides exactly what I need. } \\
\text { Airport self-service technology is my biggest concern. } \\
\text { Airport self-service technology has tailored features to suit me. } \\
\text { Airport self-service technology is customer-oriented. }\end{array}$ & $\begin{array}{l}\text { Cronin \& Taylor (1992) [77], } \\
\text { Sweeney \& Souter (2001) [30], } \\
\text { Holbrook (2006) [78], } \\
\text { Lin \& Hsieh (2011) [23] }\end{array}$ \\
\hline & Convenience & $\begin{array}{l}\text { The process of using airport self-service technology is } \\
\text { convenient. } \\
\text { Access to airport self-service technology is convenient. } \\
\text { Airport self-service technology use procedures are easy. } \\
\text { Airport self-service technology can be handled with minimal } \\
\text { effort. }\end{array}$ & $\begin{array}{l}\text { Lin \& Hsieh (2007) [5], } \\
\text { Lin \& Hsieh (2011) [23] }\end{array}$ \\
\hline \multirow[t]{2}{*}{$\begin{array}{l}\text { Response } \\
\text { (R) }\end{array}$} & $\begin{array}{l}\text { Satisfaction } \\
\text { with the } \\
\text { airport }\end{array}$ & $\begin{array}{l}\text { I am satisfied with my decision to go to this airport. } \\
\text { It was a wise choice for me to go this airport. } \\
\text { When I decided to use this airport, I thought I had made the } \\
\text { right decision. } \\
\text { I am satisfied with the overall expectation for this airport. }\end{array}$ & $\begin{array}{l}\text { Parasuraman, et al. (1985) [80], } \\
\text { Schroder et al. (2003) [39], } \\
\text { Hellier et al. (2003) [36], } \\
\text { Kotler \& Keller (2007) [37] }\end{array}$ \\
\hline & Behavioral intention & $\begin{array}{l}\text { I will continue to use self-service technology provided by the } \\
\text { airport in the future. } \\
\text { I will talk positively to people around me about the } \\
\text { self-service technology of this airport. } \\
\text { I am willing to recommend this airport self-service technology } \\
\text { to people around me. } \\
\text { I'll choose this airport again if I have the opportunity. }\end{array}$ & $\begin{array}{l}\text { Zeithaml et al. (1996) [42], } \\
\text { Cronin et al. (2000) [44], } \\
\text { Baker et al. (2000) [46], } \\
\text { Dawn (2004) [45], } \\
\text { Lin \& Hsieh (2011) [23], } \\
\text { Venkatesh (2006) [74] }\end{array}$ \\
\hline
\end{tabular}

* Note: This questionnaire uses a seven-point Likert scale.

To test the hypotheses, the data from the survey of SST users at Incheon International Airport were analyzed using the SPSS 22.0 and AMOS 18.0 programs. First, a frequency analysis was carried out to determine the respondents' demographic characteristics. Second, a confirmatory factor analysis (CFA) was performed to validate the instruments and determine inter-variable internal consistency. The hypotheses were tested using structural equation modeling (SEM) to identify the path coefficient of the structural model. From the frequency analysis, the general characteristics of the sample were as presented in Table 2. 
Table 2. Demographic information of sample.

\begin{tabular}{|c|c|c|c|}
\hline & Division & Frequency (persons) & $\%$ \\
\hline \multirow{2}{*}{ Gender } & Male & 231 & 57.7 \\
\hline & Female & 169 & 42.3 \\
\hline \multirow{6}{*}{ Age } & $10 \mathrm{~s}$ & 6 & 1.4 \\
\hline & $20 \mathrm{~s}$ & 77 & 19.3 \\
\hline & $30 \mathrm{~s}$ & 123 & 30.7 \\
\hline & $40 \mathrm{~s}$ & 113 & 28.3 \\
\hline & $50 \mathrm{~s}$ & 69 & 17.3 \\
\hline & $\geq 60$ s & 12 & 3.0 \\
\hline \multirow{5}{*}{ Education } & High school & 19 & 4.7 \\
\hline & College & 32 & 8.0 \\
\hline & University & 279 & 69.7 \\
\hline & Graduate school & 69 & 17.3 \\
\hline & Others & 1 & 0.3 \\
\hline \multirow{4}{*}{$\begin{array}{l}\text { No. of times using } \\
\text { (TBSS) }\end{array}$} & $\leq 2$ & 112 & 28.0 \\
\hline & $3-4$ & 152 & 38.0 \\
\hline & $5-6$ & 63 & 15.7 \\
\hline & $\geq 7$ & 73 & 18.3 \\
\hline \multirow{4}{*}{$\begin{array}{l}\text { Reason for use } \\
\text { (TBSS) }\end{array}$} & Recommended by acquaintances & 34 & 8.5 \\
\hline & Convenience & 102 & 25.5 \\
\hline & To save time & 259 & 64.7 \\
\hline & To use duty-free shop & 5 & 1.3 \\
\hline \multirow{4}{*}{ Airline } & Korean Air & 165 & 41.3 \\
\hline & Asiana & 81 & 20.3 \\
\hline & Foreign airline & 38 & 9.4 \\
\hline & LCC & 116 & 29.0 \\
\hline \multirow{4}{*}{$\begin{array}{l}\text { No. of trips } \\
\text { (within } 1 \text { year) }\end{array}$} & $1-3$ & 291 & 72.7 \\
\hline & $4-6$ & 93 & 23.3 \\
\hline & $7-9$ & 10 & 2.5 \\
\hline & $\geq 10$ & 6 & 1.5 \\
\hline \multirow{4}{*}{ Purpose of trip } & Tourism & 303 & 75.8 \\
\hline & Business & 82 & 20.5 \\
\hline & Visit to relatives & 9 & 2.3 \\
\hline & Others & 6 & 1.4 \\
\hline
\end{tabular}

\section{Empirical Analysis}

Before testing the hypotheses, this study validated the measurement model via the CFA. The squared multiple correlation (SMC) was estimated at $\geq 0.4$ for every item and the standardized regression coefficient was estimated at $\geq 0.7$ for the items. Therefore, convergent validity was secured. The confirmatory factor analysis of the measurement variables related to each component produced the results presented in Table 3.

In addition, this study aimed to examine the effect of the scale of the characteristics of the airport's self-service technology on the perceived value through the moderating variables (self-efficacy, waiting time). To analyze the moderating effect, the study classified the results into upper and lower groups based on the average of the analysis results and conducted a multi-group analysis. 
Table 3. Confirmatory factor analysis.

\begin{tabular}{|c|c|c|c|c|c|c|c|}
\hline Latent Variable & $\begin{array}{l}\text { Measurement } \\
\text { Variable }\end{array}$ & $\begin{array}{l}\text { Squared } \\
\text { Multiple } \\
\text { Correlation } \\
\text { (SMC) }\end{array}$ & $\begin{array}{l}\text { Standardized } \\
\text { Regression } \\
\text { Coefficient } \\
\text { (SRC) }\end{array}$ & $\begin{array}{l}\text { Non-Standardized } \\
\text { Regression } \\
\text { Coefficient } \\
\text { (NSRC) }\end{array}$ & C.R. ${ }^{a}$ & $\operatorname{AVE}^{b}$ & $\alpha^{\mathrm{c}}$ \\
\hline \multirow{4}{*}{ Function-ality } & F4 & 0.581 & 0.794 & 1.000 & & \multirow{4}{*}{0.654} & \multirow{4}{*}{0.854} \\
\hline & F3 & 0.813 & 0.763 & 0.980 & 11.557 & & \\
\hline & F2 & 0.874 & 0.757 & 1.079 & 11.506 & & \\
\hline & $\mathrm{F} 1$ & 0.734 & 0.729 & 0.881 & 11.226 & & \\
\hline \multirow{4}{*}{ Enjoyment } & E4 & 0.461 & 0.942 & 1.000 & & \multirow{4}{*}{0.68} & \multirow{4}{*}{0.964} \\
\hline & E3 & 0.790 & 0.967 & 1.045 & 42.982 & & \\
\hline & E2 & 0.786 & 0.919 & 1.016 & 34.884 & & \\
\hline & E1 & 0.736 & 0.897 & 0.929 & 32.071 & & \\
\hline \multirow{4}{*}{ Security } & S4 & 0.772 & 0.768 & 1.000 & & \multirow{4}{*}{0.58} & \multirow{4}{*}{0.915} \\
\hline & S3 & 0.901 & 0.842 & 0.988 & 18.071 & & \\
\hline & S2 & 0.918 & 0.914 & 1.083 & 19.886 & & \\
\hline & S1 & 0.864 & 0.894 & 1.090 & 19.418 & & \\
\hline \multirow{4}{*}{ Customi-zation } & C4 & 0.815 & 0.763 & 1.000 & & \multirow{4}{*}{0.66} & \multirow{4}{*}{0.883} \\
\hline & $\mathrm{C} 3$ & 0.832 & 0.838 & 1.039 & 17.442 & & \\
\hline & C2 & 0.600 & 0.872 & 1.073 & 18.215 & & \\
\hline & $\mathrm{C} 1$ & 0.835 & 0.780 & 0.902 & 16.065 & & \\
\hline \multirow{4}{*}{ Conveni-ence } & CON4 & 0.800 & 0.827 & 1.000 & & \multirow{4}{*}{0.58} & \multirow{4}{*}{0.932} \\
\hline & CON3 & 0.786 & 0.887 & 1.039 & 22.354 & & \\
\hline & CON2 & 0.684 & 0.895 & 0.995 & 22.680 & & \\
\hline & CON1 & 0.609 & 0.914 & 1.074 & 23.481 & & \\
\hline \multirow{3}{*}{ Perceived value } & PV3 & 0.761 & 0.774 & 0.925 & 19.805 & \multirow{3}{*}{0.60} & \multirow{3}{*}{0.925} \\
\hline & PV2 & 0.703 & 0.912 & 1.063 & 26.748 & & \\
\hline & PV1 & 0.582 & 0.903 & 1.000 & & & \\
\hline \multirow{4}{*}{$\begin{array}{c}\text { General } \\
\text { satisfac-tion }\end{array}$} & AOS1 & 0.799 & 0.930 & 1.000 & & \multirow{4}{*}{0.56} & \multirow{4}{*}{0.962} \\
\hline & AOS2 & 0.835 & 0.958 & 1.052 & 38.848 & & \\
\hline & AOS3 & 0.709 & 0.949 & 1.064 & 37.469 & & \\
\hline & AOS4 & 0.590 & 0.879 & 0.959 & 29.052 & & \\
\hline \multirow{4}{*}{$\begin{array}{c}\text { SST } \\
\text { Satisfac-tion }\end{array}$} & SSTS1 & 0.804 & 0.858 & 1.000 & & \multirow{4}{*}{0.61} & \multirow{4}{*}{0.892} \\
\hline & SSTS2 & 0.844 & 0.886 & 1.056 & 23.435 & & \\
\hline & SSTS3 & 0.934 & 0.889 & 1.040 & 23.549 & & \\
\hline & SSTS4 & 0.887 & 0.679 & 0.879 & 15.430 & & \\
\hline \multirow{4}{*}{$\begin{array}{l}\text { Behavioral } \\
\text { intention }\end{array}$} & BI1 & 0.532 & 0.857 & 1.000 & & \multirow{4}{*}{0.615} & \multirow{4}{*}{0.920} \\
\hline & BI2 & 0.574 & 0.935 & 1.098 & 26.574 & & \\
\hline & BI3 & 0.582 & 0.902 & 1.113 & 24.834 & & \\
\hline & BI4 & 0.553 & 0.932 & 0.917 & 18.543 & & \\
\hline
\end{tabular}

Note: ${ }^{a}$ Composite reliability.; ${ }^{\mathrm{b}}$ Average variance extracted.; ${ }^{\mathrm{c}}$ Cronbach's $\alpha$.

The CFA was followed by a measurement model analysis to test the goodness-of-fit of the model by combining all factors. For the general goodness-of-fit of the model, $\chi^{2}=1863.77, \mathrm{df}=531$, CMIN/DF $=3.51, p=0.000$, Goodness-of-Fit Index (GFI) $=0.910$, Normed Fit Index (NFI) $=0.907$, Incremental Fit Index $(\mathrm{IFI})=0.911$, Comparative Fit Index $(\mathrm{CFI})=0.910$, Root Mean Square Residual $(R M R)=0.042$, and Root Mean Square Error $($ RMSEA $)=0.079$, with each measure judged to fit CMIN/DF ( $\leq 3)$, GFI $(\geq 0.9)$, NFI $(\geq 0.9)$, IFI $(\geq 0.9)$, CFI $(\geq 0.9)$, RMR $(\leq 0.08)$, and RMSEA $(\leq 0.08)$. Therefore, the model was found to be an empirical model with a high level of goodness-of-fit. The measurement model analysis of the measurement variables related to each component produced the results presented in Table 4 . 
Table 4. Goodness-of-fit of model.

\begin{tabular}{ccccc}
\hline Division & Result & $\begin{array}{c}\text { Standard for } \\
\text { Goodness-of-Fit }\end{array}$ & Goodness-of-Fit \\
& CMIN/p & $1863.77 / 0.000$ & $p>0.05$ & Fit \\
& RMR & 0.042 & $\leq 0.05$ & Fit \\
Absolute fit index & CMIN/DF & 3.51 & $\leq 2$ & Fit \\
& GFI & 0.910 & $\geq 0.9$ & Fit \\
& AGFI & 0.903 & $\geq 0.9$ & Fit \\
& RMSEA & 0.079 & $\leq 0.05$ & Fit \\
\hline \multirow{5}{*}{ Incremental fit index } & NFI & 0.907 & $\geq 0.9$ & Fit \\
& TLI & 0.900 & $\geq 0.9$ & Fit \\
& CFI & 0.910 & $\geq 0.9$ & Fit \\
\hline \multirow{2}{*}{ Parsimony fit index } & IFI & 0.911 & $\geq 0.9$ & Fit \\
& PGFI & 0.684 & $0 \sim 1$ & Fit \\
& PNFI & 0.784 & $0 \sim 1$ & Fit \\
\hline
\end{tabular}

The results of hypothesis testing are shown in Table 5 and Figure 2. As a result of hypothesis testing, eight hypotheses (H1, H2, H4-H8, H10) were supported except two hypotheses (H3, H9). The airport self-service characteristics that statistically and significantly affected the perceived values were functionality, enjoyment, customization, and convenience. Functionality statistically and significantly affected the perceived values: $\beta=0.48$, Critical Ratio $(C R)=5.60(p<0.001)$. That is, when functionality improved, perceived value improved. Enjoyment statistically and significantly affected the perceived values: $\beta=0.10$, C.R. $=2.42(p<0.05)$. That is, when enjoyment improved, perceived value improved. Security did not have a significant effect on the perceived values. Customization statistically and significantly affected the perceived values: $\beta=0.21$, C.R. $=3.67(p<0.001)$. That is, when the level of customization improved, perceived value improved. Convenience statistically and significantly affected the perceived values: $\beta=0.17$, C.R. $=2.61(p<0.05)$. That is, when convenience improved, perceived value improved. The perceived values statistically and significantly affected SST satisfaction: $\beta=0.84$, C.R. $=19.17(p<0.001)$. That is, when perceived value improved, the level of SST satisfaction improved. The perceived values statistically and significantly affected general satisfaction with an airport: $\beta=0.87$, C.R. $=9.90(p<0.001)$. That is, when perceived value improved, the level of general satisfaction improved. The perceived values statistically and significantly affected behavioral intention: $\beta=0.64$, C.R. $=8.53(p<0.001)$. That is, when perceived value improved, behavioral intention improved. Satisfaction with SSTs at an airport did not have a significant effect on general satisfaction with the airport. Satisfaction with SSTs at an airport statistically and significantly affected the intention to behavioral intention: $\beta=0.20$, C.R. $=2.83(p<0.01)$. That is, when the level of satisfaction with SSTs at an airport improved, behavioral intention toward the airport improved. Passengers may form positive causal relations between cognitive satisfaction regarding the useful and practical benefits and the intention to reuse. This leads them to recommend or reuse TBSS. This is the very similar conclusion that $\mathrm{Lu}$ et al. [81] came to, as they considered that passengers who travel with fewer companions tend to use self-service check-in of self-bag drop. According to some authors, the savings in terms of time [18] and the long queues at desks [6] are factors that determine the use of TBSS. 
Table 5. Results of hypothesis testing.

\begin{tabular}{|c|c|c|c|c|c|c|c|c|c|}
\hline $\mathbf{H}$ & & Path & & $\mathrm{SRC}^{\mathrm{a}}$ & NSRC $^{b}$ & S.E & C.R. & $p$-Value & Decision \\
\hline H1 & Functionality & $\rightarrow$ & $\begin{array}{l}\text { Perceived } \\
\text { value }\end{array}$ & 0.486 & 0.593 & 0.106 & 5.602 & $<0.001$ & Supported \\
\hline $\mathrm{H} 2$ & Enjoyment & $\rightarrow$ & $\begin{array}{c}\text { Perceived } \\
\text { value }\end{array}$ & 0.108 & 0.097 & 0.040 & 2.428 & 0.015 & Supported \\
\hline H3 & Security & $\rightarrow$ & $\begin{array}{l}\text { Perceived } \\
\text { value }\end{array}$ & -0.023 & -0.022 & 0.034 & -0.651 & 0.515 & $\begin{array}{c}\text { Not } \\
\text { Supported }\end{array}$ \\
\hline $\mathrm{H} 4$ & Customization & $\rightarrow$ & $\begin{array}{l}\text { Perceived } \\
\text { value }\end{array}$ & 0.216 & 0.237 & 0.064 & 3.676 & $<0.001$ & Supported \\
\hline H5 & Convenience & $\rightarrow$ & $\begin{array}{l}\text { Perceived } \\
\text { value }\end{array}$ & 0.178 & 0.178 & 0.068 & 2.619 & 0.009 & Supported \\
\hline H6 & $\begin{array}{l}\text { Perceived } \\
\text { value }\end{array}$ & $\rightarrow$ & $\begin{array}{c}\text { SST } \\
\text { Satisfaction }\end{array}$ & 0.846 & 0.719 & 0.037 & 19.174 & $<0.001$ & Supported \\
\hline $\mathrm{H} 7$ & $\begin{array}{l}\text { Perceived } \\
\text { value }\end{array}$ & $\rightarrow$ & $\begin{array}{l}\text { General } \\
\text { satisfaction }\end{array}$ & 0.873 & 0.816 & 0.082 & 9.909 & $<0.001$ & Supported \\
\hline $\mathrm{H} 8$ & $\begin{array}{l}\text { Perceived } \\
\text { value }\end{array}$ & $\rightarrow$ & $\begin{array}{l}\text { Behavioral } \\
\text { intention }\end{array}$ & 0.645 & 0.540 & 0.063 & 8.532 & $<0.001$ & Supported \\
\hline $\mathrm{H} 9$ & $\begin{array}{c}\text { SST } \\
\text { Satisfaction }\end{array}$ & $\rightarrow$ & $\begin{array}{l}\text { General } \\
\text { satisfaction }\end{array}$ & -0.170 & -0.187 & 0.094 & -1.901 & 0.058 & $\begin{array}{c}\text { Not } \\
\text { Supported }\end{array}$ \\
\hline $\mathrm{H} 10$ & $\begin{array}{c}\text { SST } \\
\text { Satisfaction }\end{array}$ & $\rightarrow$ & $\begin{array}{l}\text { Behavioral } \\
\text { intention }\end{array}$ & 0.207 & 0.204 & 0.072 & 2.833 & 0.005 & Supported \\
\hline
\end{tabular}

Note: ${ }^{a}$ Standardized regression coefficient.; ${ }^{\mathrm{b}}$ Non-standardized regression coefficient.

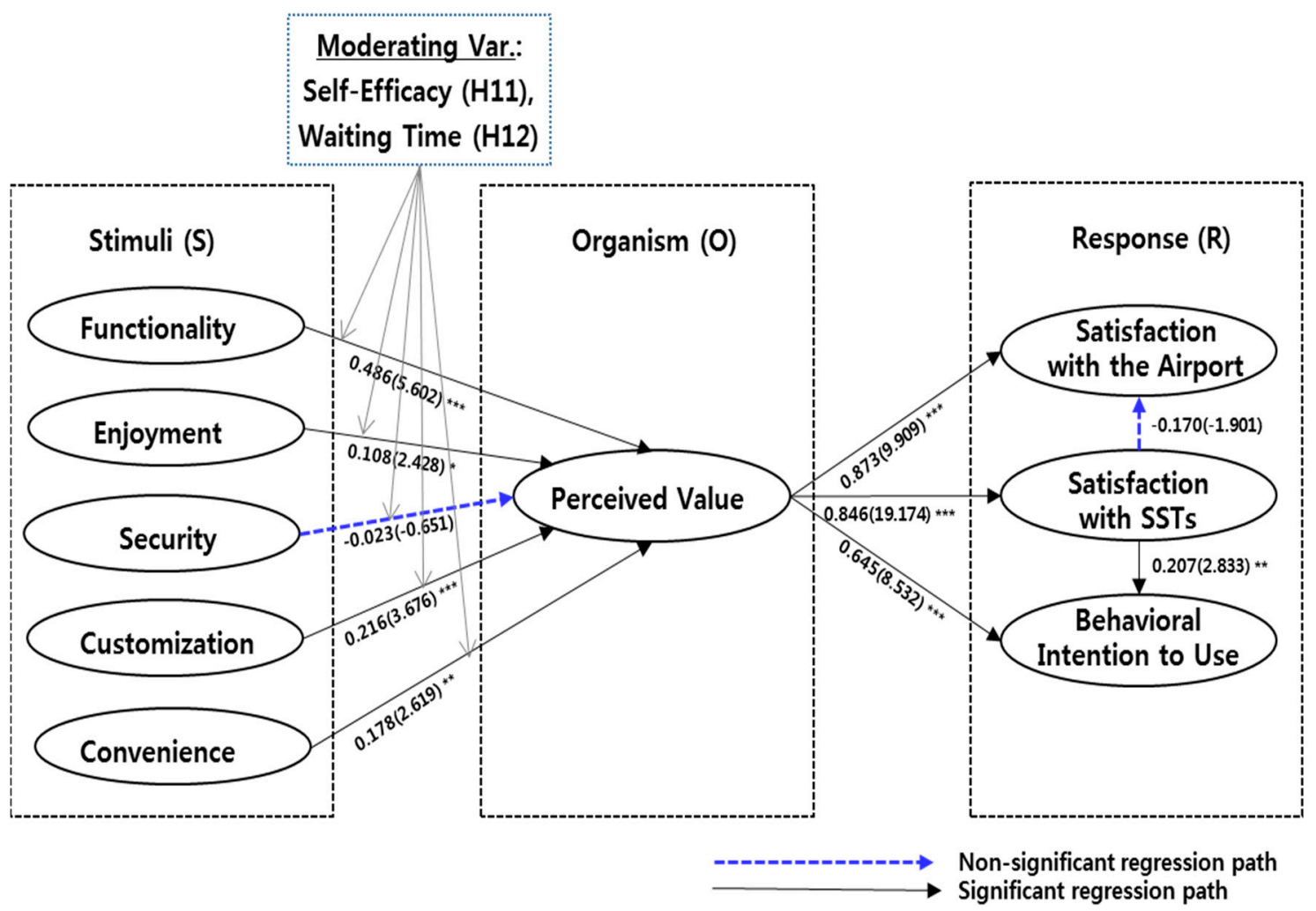

Figure 2. Research result of hypotheses testing.

The results of analyzing the effect of the moderating effect on individual's self-efficacy on TBSS characteristics and perceived value, the constrained model showed that enjoyment and customization had moderating effects with a chi-square variation of $\Delta \mathrm{df}=1$, which was greater than $\Delta \chi^{2}=3.84$ for the significant differences (Table 6). Functionality, security, and convenience had no moderating effects, with chi-square variations smaller than $\Delta \chi^{2}=3.84$. Therefore, the hypothesis 11 was partially supported. Both high and low levels of self-efficacy had functionality and customization statistically 
significantly affect the perceived values, with the effects being greater in the group of high self-efficacy than in that of low self-efficacy (Table 6). This result further supports the findings of previous studies that demonstrated the importance of self-efficacy in the use of SSTs [26,82]. Positive TBSS users at airports were generally satisfied, intended to use it continuously, and even had their word-of-mouth intention affected. These results are similar to the previous studies $[27,59,83]$ in which the moderating effect of self-efficacy played a positive role in satisfaction and reuse intention.

Table 6. Moderating effect of self-efficacy.

\begin{tabular}{|c|c|c|c|c|c|}
\hline \multicolumn{2}{|c|}{ Path } & $x^{2}$ & df & $\Delta \mathrm{x}^{2} / \Delta \mathrm{df}$ & $\Delta \mathrm{df}$ \\
\hline \multicolumn{2}{|c|}{ Unconstrained model } & 2471.01 & 1084 & 228 & \\
\hline \multirow{5}{*}{$\begin{array}{c}\text { Constrained } \\
\text { model }\end{array}$} & Functionality & 2471.24 & 1085 & 0.23 & 1 \\
\hline & Enjoyment & 2483.32 & 1085 & 12.31 & 1 \\
\hline & Security & 2473.67 & 1085 & 2.66 & 1 \\
\hline & Customization & 2481.51 & 1085 & 10.50 & 1 \\
\hline & Convenience & 2471.60 & 1085 & 0.59 & 1 \\
\hline
\end{tabular}

The multi-group analysis of the moderating effects of self-efficacy showed that the group with the greater mean for self-efficacy had functionality significantly affect the perceived values $(p<0.001)$. Customization significantly affected the perceived values $(p<0.05)$. The group with the smaller mean for self-efficacy had functionality and enjoyment significantly affect the perceived values $(p<0.001)$. In addition, security $(p<0.05)$, customization $(p<0.01)$, and convenience $(p<0.05)$ significantly affected the perceived values (Table 7).

Table 7. Path analysis of self-efficacy moderating model.

\begin{tabular}{|c|c|c|c|c|c|c|c|}
\hline Group & Path & & $\begin{array}{l}\text { Standardized } \\
\text { Estimates }\end{array}$ & Estimates & $\begin{array}{l}\text { Standard } \\
\text { Deviation }\end{array}$ & $\begin{array}{c}\text { Critical } \\
\text { Ratio }\end{array}$ & $p$-Value \\
\hline \multirow{5}{*}{$\begin{array}{l}\text { Upper } \\
\text { group }\end{array}$} & Functionality & \multirow{5}{*}{$\begin{array}{l}\text { Perceived } \\
\text { value }\end{array}$} & 0.479 & 0.617 & 0.185 & $3.327 * * *$ & $<0.001$ \\
\hline & Enjoyment & & 0.03 & 0.028 & 0.071 & 0.396 & 0.692 \\
\hline & Security & & 0.06 & 0.061 & 0.062 & 0.985 & 0.324 \\
\hline & Customization & & 0.249 & 0.297 & 0.138 & $2.157^{*}$ & 0.031 \\
\hline & Convenience & & 0.109 & 0.118 & 0.098 & 1.204 & 0.228 \\
\hline \multirow{5}{*}{$\begin{array}{l}\text { Lower } \\
\text { group }\end{array}$} & Functionality & \multirow{5}{*}{$\begin{array}{l}\text { Perceived } \\
\text { value }\end{array}$} & 0.446 & 0.507 & 0.133 & $3.8^{* * *}$ & $<0.001$ \\
\hline & Enjoyment & & 0.193 & 0.159 & 0.047 & $3.357^{* * *}$ & $<0.001$ \\
\hline & Security & & -0.1 & -0.081 & 0.039 & -2.101 * & 0.036 \\
\hline & Customization & & 0.195 & 0.185 & 0.07 & $2.633^{* *}$ & 0.008 \\
\hline & Convenience & & 0.224 & 0.236 & 0.113 & $2.09 *$ & 0.037 \\
\hline
\end{tabular}

Note: ${ }^{*} p<0.05,{ }^{* *} p<0.01,{ }^{* * *} p<0.001$.

The results of analyzing the effect of the moderating effect on individual's waiting time on TBSS characteristics and perceived value, the constrained model showed that security and convenience had moderating effects with a chi-square variation of $\Delta \mathrm{df}=1$, which was greater than $\Delta \chi^{2}=3.84$ for significant differences (Table 8). Functionality, enjoyment, and customization had no moderating effects with chi-square variations smaller than $\Delta \chi^{2}=3.84$. Therefore, the hypothesis 12 was partially supported. 
Table 8. Moderating effect of waiting time.

\begin{tabular}{cccccc}
\hline \multicolumn{2}{c}{ Path } & $\boldsymbol{\chi}^{2}$ & $\mathbf{d f}$ & $\Delta \boldsymbol{\chi}^{2} / \Delta \mathbf{d f}$ & $\Delta \mathbf{d f}$ \\
\hline Unconstrained model & 2382.97 & 1084 & 2.19 & \\
\hline \multirow{2}{*}{ Constrained } & Functionality & 2385.22 & 1085 & 2.25 & 1 \\
model & Enjoyment & 2384.15 & 1085 & 1.18 & 1 \\
& Security & 2391.31 & 1085 & 8.34 & 1 \\
& Customization & 2386.71 & 1085 & 3.74 & 1 \\
& Convenience & 2392.17 & 1085 & 9.20 & 1 \\
\hline
\end{tabular}

The multi-group analysis of the moderating effects of perceived waiting time by the waiting conditions in using TBSS at airports showed that the group with the greater mean for awareness of waiting time had functionality and customization significantly affect the perceived values $(p<0.001)$. Security significantly affected the perceived values $(p<0.05)$. The group that was less aware of the waiting time had functionality $(p<0.05)$, enjoyment $(p<0.01)$, and convenience $(p<0.001)$ significantly affect the perceived values (Table 9 ). Those who were either more or less aware of the waiting time had functionality statistically significantly affect the perceived value. In addition, the physical environment was required to a greater extent than the environment of personal service during the process of experiencing waiting in the TBSS use environment at an airport.

Table 9. Path analysis of waiting time moderating model.

\begin{tabular}{|c|c|c|c|c|c|c|c|}
\hline Group & Path & & $\begin{array}{l}\text { Standardized } \\
\text { Estimates }\end{array}$ & Estimates & $\begin{array}{l}\text { Standard } \\
\text { Deviation }\end{array}$ & $\begin{array}{c}\text { Critical } \\
\text { Ratio }\end{array}$ & $p$-Value \\
\hline \multirow{5}{*}{$\begin{array}{l}\text { Upper } \\
\text { group }\end{array}$} & Functionality & \multirow{5}{*}{$\begin{array}{l}\text { Perceived } \\
\text { value }\end{array}$} & 0.627 & 0.717 & 0.133 & $5.396^{* * *}$ & $<0.001$ \\
\hline & Enjoyment & & 0.076 & 0.068 & 0.052 & 1.307 & 0.191 \\
\hline & Security & & -0.113 & -0.102 & 0.044 & $-2.328 *$ & 0.020 \\
\hline & Customization & & 0.310 & 0.338 & 0.088 & $3.848^{* * *}$ & $<0.001$ \\
\hline & Convenience & & 0.026 & 0.028 & 0.097 & 0.284 & 0.777 \\
\hline \multirow{5}{*}{$\begin{array}{l}\text { Lower } \\
\text { group }\end{array}$} & Functionality & \multirow{5}{*}{$\begin{array}{l}\text { Perceived } \\
\text { value }\end{array}$} & 0.270 & 0.392 & 0.161 & $2.427 *$ & 0.015 \\
\hline & Enjoyment & & 0.160 & 0.151 & 0.055 & $2.730 * *$ & 0.006 \\
\hline & Security & & 0.088 & 0.091 & 0.050 & 1.807 & 0.071 \\
\hline & Customization & & 0.105 & 0.109 & 0.077 & 1.422 & 0.155 \\
\hline & Convenience & & 0.447 & 0.440 & 0.092 & $4.786^{* * *}$ & $<0.001$ \\
\hline
\end{tabular}

Note: ${ }^{*} p<0.05,{ }^{* *} p<0.01,{ }^{* * *} p<0.001$.

\section{Discussion}

This study applied the SOR integrated model, which is mainly used to identify consumer behavior in the behavioral science field, to analyze the effect of TBSS characteristic factors (five factors) on the perceived value of passengers through the moderating variables (self-efficacy and waiting time), and to investigate the effect of these perceived values on satisfaction (SSTs, airport) and behavioral intention. The empirical analysis of 400 passengers using SSTs at airports obtained the following results. First, four TBSS characteristics-functionality, enjoyment, customization, and convenience-statistically and significantly affected the perceived values. This finding implies that those who believe that technologies make their daily life and work convenient are more likely to think that TBSS is easy to use and efficient. In contrast, security did not have a significant effect on perceived values. Second, higher perceived values significantly affected TBSS satisfaction, general satisfaction with the airport, and behavioral intention. Customers perceiving higher TBSS values had customer satisfaction more strongly affected. In contrast, satisfaction with TBSS at an airport did not have a significant effect on general satisfaction with the airport. Third, the multi-group analysis of the moderating effects of self-efficacy showed that the group with the greater mean for self-efficacy had functionality and customization significantly affect the perceived values and the group with the smaller mean for self-efficacy had functionality have the most significant impact, followed by enjoyment, customization, security, and convenience. 
Thus, through the moderating effect of individual self-efficacy on TBSS, the influence relationship on perceived values and behavioral intention was verified. It can be said that customer's self-efficacy is a crucial moderating variable in using TBSS. Fourth, the multi-group analysis of the moderating effects of waiting time showed that the group less aware of waiting time had functionality, followed by customization, security, enjoyment, and convenience, most significantly affect the perceived values. The group more aware of waiting time had convenience, followed by enjoyment, functionality, security, and customer satisfaction, most significantly affect the perceived values. In addition, it was shown that the physical environment was required to a greater extent than the environment of personal service during the process of experiencing waiting in the TBSS environment at an airport. This implies that expanding customized TBSS facilities and offering better convenience facilities through the realization of the smart airport environment is considered as a more important service factor.

\section{Conclusions}

This study has analyzed the effects of airport self-service characteristics on behavioral intention. The implications of this study are as follows. First, while most of the previous studies analyzed the effects of SST acceptance on the intention to reuse in passengers at airports, this study is academically significant in that it applied the SOR model and the moderating variables (self-efficacy and waiting time) to determine the effects of various psychological responses of TBSS users and the TBSS environment of the airport (facilities and systems) on satisfaction and behavioral intention. Second, a practical implication of this study is that it demonstrated that the goal of using SSTs at airports was to realize time saving and convenience in use, thanks to quick check-ins, as confirmed by the results. Therefore, efforts to carefully analyze differences in technology acceptance by age or generation, as well as efforts to improve user satisfaction by enhancing every user's self-efficacy and efficiently managing cognitive and emotional waiting time, are expected to have positive effects on behavioral intention. Third, this study has the following policy implication. It is necessary to develop a strategy to activate SSTs and differentiate services at airports in preparation for globally infinite competition. To gradually expand the application of TBSS and operate it stably, priority should be given to efforts to generate a platform for the integrated management of information in all the areas at airports, including information about aircraft and passenger flow, by integrating individual systems and by building information platforms. What is necessary at the same time is to expand TBSS by applying up-to-date technologies, including unmanned systems, which involve self-check-in kiosks, self-tagging of checked luggage, self-bag drops, and biometrics-based immigration systems.

The limitations of this study and further tasks are as follows. Because this study only surveyed South Korean TBSS users, the sample is hardly representative. This limitation will be overcome by conducting a survey in a population containing broader range of nationalities. While the empirical research found that the TBSS characteristics at airports significantly affected the perceived values, customer satisfaction, and behavioral intention, further research should be conducted in several resulting variables, including diverse situational effects, moderating variables, and customer satisfaction segmentation.

Author Contributions: Conceptualization, J.-H.K. and J.-W.P.; methodology, J.-H.K. and J.-W.P.; data collection and analysis, J.-H.K.; supervision of the research, J.-W.P.; writing-original draft, J.-H.K.; writing-review \& editing J.-H.K. and J.-W.P.

Funding: This research received no external funding.

Acknowledgments: As the authors of this study, we want to express our gratitude to the SST users at Incheon International Airport who completed the questionnaire. We also want to express our gratitude to Incheon International Airport for having been willing to participate in the survey.

Conflicts of Interest: The authors declare no conflict of interest. 


\section{References}

1. Snowdon, E.; MacNair, M.; Montevecchi, C.A.; Callery, S. IBM journey management library: An Arena System for Airport Simulations. J. Ope. Res. Soc. 2000, 51, 449-456. [CrossRef]

2. Chang, H.L.; Yang, C.H. Do airline self-service check-in kiosks meet the needs of passengers? J. Tour. Manag. 2008, 29, 980-993. [CrossRef]

3. Incheon International Airport Corporation. Incheon Airport Business Statistics Report; Incheon International Airport Corporation: Incheon, Korea, 2018.

4. Castillo-Manzano, J.I.; López-Valpuesta, L. Check-in services and passenger behaviour: Self service technologies in airport systems. J. Comp. Human Behav. 2013, 29, 2431-2437. [CrossRef]

5. Lin, C.; Hsieh, P.L. The influence of technology readiness on satisfaction and behavioral intentions toward self-service technologies. J. Comput. Hum. Behav. 2007, 23, 1597-1615. [CrossRef]

6. Gelderman, C.J.; Ghijsen, P.W.; Diemen, R.V. Choosing self-service technologies or interpersonal services -The impact of situational factors and technology related attitudes. J. Retailing Consum. Serv. 2011, 18, 414-421. [CrossRef]

7. Lisha, C.F.; Goh, S.; Yifan, A. Integrating guanxi into technology acceptance: An empirical investigation of WeChat. J. Telemat. Inform. 2017, 34, 1125-1142. [CrossRef]

8. Bandura, A. Social Foundations of Thought and Action: A Social Cognitive Theory; Prentice-Hall: Englewood Cliffs, NJ, USA, 1986; ISBN 978-0-13-815614-5.

9. Djelassia, S.; Diallob, M.F.; Zielkec, S. How self-service technology experience evaluation affects waiting time and customer satisfaction? A moderated mediation model. J. Decis. Support Syst. 2018, 111, 38-47. [CrossRef]

10. Mehrabian, A.; Russell, J.A. An Approach to Environmental Psychology; The MIT Press: Cambridge, MA, USA, 1974.

11. Belk, R.W. Situational Variables and Consumer Behaviour. J. Consum. Res. 1975, 2, 157-164. [CrossRef]

12. Eroglu, S.A.; Machleit, K.A.; Davis, L.M. Atmospheric Qualities of Online Retailing: A Conceptual Model and Implications. J. Bus. Res. 2001, 54, 177-184. [CrossRef]

13. Bagozzi, R.P. Principles of Marketin Management; Science Research Associates: Chicago, IL, USA, 1986; Volume 2, pp. 58-68.

14. Sherman, E.; Mathur, A.; Smith, R.B. Store Environment and Consumer Purchase Behaviour: Mediating Role of Consumer Emotions. Psychol. Mark. 1997, 14, 361-378. [CrossRef]

15. Jacoby, J. Stimulus-Organism-Response reconsidered: An evolutionary step in modeling (consumer) behavior. J. Consumer Psychol. 2002, 12, 51-57. [CrossRef]

16. Chen, C.C.; Yao, J.Y. What drives impulse buying behaviors in a mobile auction? The perspective of the Stimulus-Organism-Response model. J. Telemat. Inform. 2018, 35, 1249-1262. [CrossRef]

17. Dabholkar, P.A. Consumer Evaluations of New Technology-based Self-Service Options: An Investigation of Alternative Models of Service Quality. Int. J. Res. Mark. 1996, 13, 29-51. [CrossRef]

18. Meuter, M.; Ostrom, A.; Roundtree, R.; Bitner, M. Self-service technologies understanding customer satisfaction with technology-based service encounters. J. Mark. 2000, 64, 50-64. [CrossRef]

19. Liljander, V.; Gillbert, F.; Gummerus, J.; Van Riel, A. Technology Readiness and The Evaluation and Adoption of Self-Service Technologies. J. Retail Consum Serv. 2006, 13, 177-191. [CrossRef]

20. Johnson, M.D. Consumer Choice Strategies for Comparing Non-Comparable Alternatives. J. Consum. Res. 1984, 11, 741-753. [CrossRef]

21. Zhu, F.A.; Walter, W.J.; Chen, I. IT-based Services and Services Quality in Consumer Banking. Int. J. Serv. Indus. Manag. 2012, 13, 69-90. [CrossRef]

22. Ahn, J.A.; Seo, S. Consumer Responses to Interactive Restaurant Self-Service Technology. Int. J. Hosp. Manag. 2018, 74, 109-121. [CrossRef]

23. Lin, C.; Hsieh, P.L. Assessing the Self-Service Technology Encounters: Development and Validation of SSTQUAL Scale. J. Retail. 2011, 87, 194-206. [CrossRef]

24. Chen, C.F.; Chen, F.S. Experience quality, perceived value, satisfaction and behavioral intentions for heritage tourists. J. Tour. Manag. 2010, 31, 29-35. [CrossRef]

25. Zeithaml, V.A. Consumer Perceptions of Price, Quality, and Value: A Means-end Model and Synthesis of Evidence. J. Mark. 1988, 52, 2-23. [CrossRef] 
26. Wang, C.; Harris, J.; Patterson, P. The roles of habit, self-efficacy, and satisfaction in driving continued use of self-service technologies: a longitudinal study. J. Serv. Res. 2013, 16, 400-414. [CrossRef]

27. Lee, H.S.; Choi, S.Y.; Kang, Y.S. Formation of e-satisfaction and repurchase intention: Moderating roles of computer self-efficacy and computer anxiety. J. Expert Sys. Appl. 2009, 36, 7848-7859. [CrossRef]

28. Marimon, F.; Vidgen, R.; Barnes, S.; Cristóbal, E. Purchasing behaviour in an online supermarket: the applicability of ES-QUAL. Int. J. Mark. Res. 2010, 52, 111-129.

29. Sigala, M. Mass customisation implementation models and customer value in mobile phones services: preliminary findings from Greece. Int. J. Manag. Serv. Qual. 2006, 16, 395-420. [CrossRef]

30. Sweeney, J.C.; Souter, G.N. Consumer Perceived Value: The Development of A Multiple Item Scale. J. Retail 2001, 77, 203-220. [CrossRef]

31. Eggert, A.; Ulaga, W. Customer Perceived Value: A Substitute for Satisfaction in Business Markets. J. Bus Indus Mark. 2002, 17, 107-118. [CrossRef]

32. Lam, S.Y.; Shankar, V.; Erramilli M., K.; Murthy, B. Customer Value, Satisfaction, Loyalty, and Switching Costs: An Illustration from A Business-to-Business Service Context. J. Acad. Mark. Sci. 2004, 32, $293-311$. [CrossRef]

33. McDougal, G.H.; Levesque, T. Customer Satisfaction with Services: Putting Perceived Value into the Equation. J. Serv. Mark. 2000, 14, 392-410. [CrossRef]

34. Zhou, L. Sevice Quality and Satisfaction in China's Retail Banking. J. Serv. Mark. 2004, 18, 534-546. [CrossRef]

35. Oliver, R.L. A Cognitive Model of The Antecedents and Consequences of Satisfaction Decisions. J. Mark. Res. 1980, 17, 460-469. [CrossRef]

36. Hellier, P.K.; Geursen, G.M.; Carr, R.A.; Rickard, J.A. Customer Repurchase Intention: A General Structural Equation Model. Eur. J. Mark. 2003, 37, 1762-1800. [CrossRef]

37. Kotler, P.; Keller, K.L. Marketing Management, 12th ed.; Seokjeong Publishing Co.: Seoul, South Korea, 2007.

38. Gopinath, M.; Nyer, P.U. The Effect of Public Commitment on Resistance to Persuasion: The Influence of Attitude Certainty, Issue Importance, Susceptibility to Normative Influence, Preference for Consistency and Source Proximity. Int. J. Res. Mark. 2009, 26, 60-68. [CrossRef]

39. Odekerken-Schröder, G.; De Wulf, K.; Schumacher, P. Strengthening Outcomes of Retailer-Consumer Relationships: The Dual Impact of Relationship Marketing Tactics and Consumer Personality. J. Bus. Res. 2003, 56, 177-190. [CrossRef]

40. Davis, F.D. Perceived Usefulness, Perceived Ease of Use, and User Acceptance of Information Technology. MIS Q. 1989, 13, 318-339. [CrossRef]

41. Ajzen, I. The theory of planned behaviour. Organ. Behav. Hum. Dec. 1991, 50, 179-211. [CrossRef]

42. Zeithaml, V.A.; Berry, L.L.; Parasuraman, A. The Behavioural Consequence of Service Quality. J. Mark. 1996, 60, 31-46. [CrossRef]

43. Wong, C.S.; Kwong, W.Y. Outbound Tourists Selection Criteria for Choosing All-Inclusive Package Tours. J. Tour. Manag. 2004, 25, 581-592. [CrossRef]

44. Cronin, J.J.; Brady, M.K.; Hutl, G.T.M. Assessing the Effects of Quality, Value, and Customer Satisfaction on Customer Behavioral Intentions in Service Environments. J. Retail. 2000, 76, 193-218. [CrossRef]

45. Dawn, B.L.; Thomas, L.P. The Impact of Structure and Process Attributes on Satisfaction and Behavioral Intentions. J. Serv. Mark. 2004, 18, 114-121.

46. Baker, D.A.; Crompton, J.L. Quality, Satisfaction and Behavioral Intentions. Ann. Tour. Res. 2000, 27, 785-804. [CrossRef]

47. Schunk, D.H. Self-efficacy and Academic Motivation. Edu. Psychol. 1991, 26, 207-231. [CrossRef]

48. Gist, M.E.; Mitchell, T.R. Self-efficacy: A Theoretical Analysis of Its Determinants and Malleability. Acad. Manag. Rev. 1992, 17, 183-211. [CrossRef]

49. Bandura, A. A Self-Efficacy: Toward a Unifying Theory of Behavioural Change. Psychol. Rev. 1977, 82, 191-215. [CrossRef]

50. Bandura, A. Self-Efficacy Mechanism in Human Agency. Am. Psychol. 1982, 37, 122-147. [CrossRef]

51. Sherer, M.; Maddux, J.E.; Mercandante, B.; Prentice-Dunn, S.; Jacobs, B.; Rogers, R.W. The self-efficacy scale: Construction and validation. Psychol. Rep. 1982, 51, 663-671. [CrossRef]

52. Delroy, L.P.; Mark, V.S. The spheres of control scale: 10yr of research. Personality Individual Differences 1990, 11, 1029-1036. 
53. Huebner, E.S. Burnout among school psychologists: An exploratory investigation into its nature, extent and correlates. Sch. Psychol. Q. 1992, 7, 129-136. [CrossRef]

54. Gardner, D.G.; Pierce, J.L. Self-esteem and self-efficacy within the organizational context. Group Organ. Manag. 1998, 23, 48-70. [CrossRef]

55. Dabholkar, P.A.; Bagozzi, R.P. An attitudinal model of technology based self-service: moderating effects of consumer traits and situational factors. J. Acad. Market. Sci. 2002, 30, 184-201. [CrossRef]

56. Shamdasni, P.; Mukherjee, A.; Malhotra, N. Antecedents and dconsequences of service quality in consumer evaluation of self-service internet technologies. Serv. Ind. J. 2008, 28, 117-138. [CrossRef]

57. Hill, K.; Startup, M. The relationship between internalized stigma, negative symptoms and social functioning in schizophrenia: The mediating role of self-efficacy. J. Psych. Res. 2013, 206, 151-157. [CrossRef] [PubMed]

58. Deforche, B.D.; Dyck, V.; Verloigne, M.; Bourdeaudhuij, I.D. Perceived social and physical environmental correlates of physical activity in older adolescents and the moderating effect of self-efficacy. J. Prev. Med. 2010, 50, S24-S29. [CrossRef] [PubMed]

59. Sung, H.N.; Shin, J.I. The Effect of Self-Efficacy on Behavioral Intention through Expectancy, Social Influence, and Facilitating Conditions in Mobile Learning: The Moderating Effect of Gender. J. Electron. Commer. Res. 2017, 17, 39-52.

60. Taylor, S. Waiting for Service: The Relationship Between Delays and Evaluations of Service. J. Mark. 1994, 5, 56-69. [CrossRef]

61. Davis, M.M.; Vollmann, T.E. A Framework for Relating Waiting Time and Customer Satisfaction in a Service Operation. J. Serv. Mark. 1990, 4, 61-69. [CrossRef]

62. Davis, M.J.; Maggard, M. An Analysis of Customer Satisfaction with Waiting Times in a Two-Stage Service Process. J. Ope. Manag. 1990, 9, 61-69. [CrossRef]

63. Gardner, M.P. Mood States and Consumer Behaviour: A Critical Review. J. Consum. Res. 1985, 12, $281-300$. [CrossRef]

64. Osuna, E. The psychological cost of waiting. J. Mathem. Psych. 1985, 29, 82-105. [CrossRef]

65. Katz, K.L.; Larson, B.M.; Larson, R.C. Prescription for the waiting-in-line blues: Entertain, enlighten, and engage. MIT Sloan Manag. Rev. 1991, 32, 44-53.

66. Butchera, K.; Heffernanb, T. Social regard: a link between waiting for service and service outcomes. Int. J. Hosp. Manag. 2006, 25, 34-53. [CrossRef]

67. Kokkinou, A.; Cranage, D.A. Using self-service technology to reduce customer waiting times. Int. J. Hosp. Manag. 2013, 33, 435-445. [CrossRef]

68. Pruyn, A.; Smidts, A. Effects of waiting on the satisfaction with the service: Beyond objective time measures. Int. J. Res. Mark. 1998, 15, 321-334. [CrossRef]

69. Oliver, R.L. Satisfaction: Behavioural Perspective on the Consumer; McGraw-Hill: New York, NY, USA, 1997; Volume 14, pp. 4-5.

70. Martin, B.A.S.; Sherrard, M.J.; Wentzel, D. The Role of Sensation Seeking and Need for Cognition on Web-site Evaluations: A Resource Matching Perspective. Psychol. Mark. 2005, 4, 47-62. [CrossRef]

71. Wang, Y.; Lin, H.; Luarn, P. Predicting consumer intention to use mobile service. J. Inform. Sys. 2006, 16, 157-179. [CrossRef]

72. Collier, J.E.; Sherrell, D.L. Examining the influence of control convenience in a self-service setting. J. Acad. Market. Sci. 2010, 38, 490-509. [CrossRef]

73. Eighmey, J.; McCord, L. Adding value in the information age: Uses and gratifications of sites on the world wide web. J. Bus. Res. 1998, 41, 187-194. [CrossRef]

74. Venkatesh, V. Where to go from here? Thoughts on future directions for research on individual-level technology adoption with a focus on decision making. J. Decis. Sci. 2006, 37, 497-518. [CrossRef]

75. Collier, S.E. Only if it is convenient: understanding how convenience influences self-service technology evaluation. J. Serv. Res. 2013, 16, 39-51. [CrossRef]

76. Parasuraman, A. Technology Readiness Index (TRI): a multiple-item scale to measure readiness to embrace new technologies. J. Serv. Res. 2000, 2, 307-320. [CrossRef]

77. Cronin, J.J.; Taylor, S.A. Measuring service quality: A reexamination and extension. J. Mark. 1992, 56, 55-68. [CrossRef]

78. Holbrook, M.B. Consumption experience, customer value, and subjective personal introspection: An illustrative photographic essay. J. Bus. Res. 2006, 59, 714-725. [CrossRef] 
79. Meuter, M.; Ostrom, A.; Roundtree, R.; Bitner, M. The influence of technology anxiety on consumer use and experiences with self-service technologies. J. Bus. Res. 2003, 56, 899-906. [CrossRef]

80. Parasuraman, A.; Zeithaml, V.A.; Berry, L.L. A conceptual model of service quality and its implications for future research. J. Mark. 1985, 41-50. [CrossRef]

81. Lu, J.L.; Choi, J.K.; Tseng, W.C. Determinants of passengers' choice of airline check-in service: A case study of American, Australian, Korean, and Taiwanese passengers. J. Air Transp. Manag. 2011, 17, 249-252. [CrossRef]

82. Beuningen, J.; Ruyter, K.D.; Wetzels, M.; Streukens, S. Customer self-efficacy in technology-based self-service: assessing between- and withinperson differences. J. Serv. Res. 2009, 11, 407-428. [CrossRef]

83. Yoo, C.W.; Goo, J.H.; Huang, C.D.; Nam, K.H.; Woo, M.N. Improving travel decision support satisfaction with smart tourism technologies: A framework of tourist elaboration likelihood and self-efficacy. J. Technol. Forecast. Soc. Chang. 2017, 123, 330-341. [CrossRef]

(C) 2019 by the authors. Licensee MDPI, Basel, Switzerland. This article is an open access article distributed under the terms and conditions of the Creative Commons Attribution (CC BY) license (http://creativecommons.org/licenses/by/4.0/). 